\title{
Opinions of Science Teachers for Classroom Management
}

\author{
Ulas Kubat ${ }^{1} \bowtie$ (iD \\ Nurhak Cem Dedebali ${ }^{2}$
}

'MuglaSitkı Kocman University, Faculty of Education, Turkey Email:ulaskubat@mu.edu.tr+90252-211-1761

-Sinop University, Faculty of Education, Turkey

Email: dedebali40@,hotmail.com +90368-271-5526

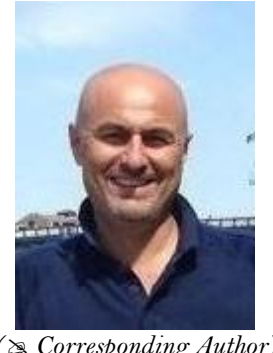

\begin{abstract}
This study investigates science teachers' concerns about how to achieve effective classroom management, with particular reference to classroom communication, student motivation, physical environments and unwanted student behaviors. A qualitative research method is used in this research. The semi-structured interview form is developed by the researchers as a data collection tool. The study group consists of fourteen science teachers who are working in Mugla province of Turkey, in the academic year of 2015-2016. According to the research findings, participating teachers have linked effective classroom communications to such aspects as student participation and a democratic and sincere classroom environment. In addition, they have also stated that effective classroom management are linked to the following: proper material usage, asking questions, feeling the importance of lessons, physical environment, laboratory environment, a Ushaped seating plan, use of an interactive whiteboard, verbal warnings to correct undesirable behaviors, trying to understand the causes of problems, giving responsibility, establishing eye contact, proper punishments, interviewing parents, guiding teachers and sending students to principal's room.
\end{abstract}

Keywords: Classroom management, Classroom communication, Unwanted behavior.

Citation | Ulas Kubat; Nurhak Cem Dedebali (2018). Opinions of Science Teachers for Classroom Management. Journal of Education and e-Learning Research, 5(2): 110-117.

History:

Received: 4 May 2018

Revised. 23 May 9018

Accepte 29 May 2018

Accepted: 29 May 2018

Published: 4 June 2018

Licensed: This work is licensed under a Creative Commons

Attribution 3.0 License (c)

Publisher:Asian Online Journal Publishing Group
Contribution/Acknowledgement: Both authors contributed to the conception and design of the study.

Funding: This study received no specific financial support

Competing Interests: The authors declare that they have no conflict of interests.

Transparency: The authors confirm that the manuscript is an honest, Transparency: The authors confirm that the manuscript is an honest,
accurate, and transparent account of the study was reported; that no vital accurate, and transparent account of the study was reported; that no vital
features of the study have been omitted; and that any discrepancies from the study as planned have been explained.

Ethical: This study follows all ethical practices during writing.

\section{Contents}

1. Introduction

3. Results

References. 


\section{Introduction}

Classroom management is the process of planning and organizing classroom resources for a certain purpose Arı and Deniz (2008). In classroom management, communication, motivation, physical environment, unwanted behavior control and time management are very important. Establishing the environment where teaching takes place, using time effectively, determining class rules, and establishing an effective communication environment, constitute the most basic goals of classroom management. Classroom management is a process to enhance students' involvement and cooperation in classroom discussion and activities (Roelofs et al., 1994). As stated by Jones (2000) classroom management is a "system that includes instructional strategies focused on making students independent and resourceful, motivational strategies that help students to be more conscientious and accountable, and discipline strategies that reduce goofing off'. Teachers are sometimes unaware of what they do or why they engage in a classroom practice. This lack of perception can result in unproductive behavior (Good and Brophy, 2008).

The physical variables of the learning-teaching environment are the number of students, heating, lighting, appearance, wall and furniture colors, noise, cleanliness and seating. All these variables can influence the learningteaching process. According to Evertson et al. (1997) for the physical layout of the class:

1. Determine the areas where teachers and students can move easily.

2. To make sure that students can make eye contact with the teacher continuously.

3. Teaching tools are easily accessible.

4. Making sure students can see the activities easily in the classroom.

The effective communication skills between student and teacher as well as between student and student will create a positive classroom environment. This will affect student achievement positively. Students mostly see teachers that they love and respect as leaders (Levine, 2009). The rules for disciplinary problems that can occur in the classroom are one of the most effective classroom management tools (Mackanzie and Stanzione, 2010). The course and behavioral rules will prevent disciplinary problems that may arise in the future. Otherwise, a higher likelihood of disciplinary problems may occur, that would cause an interruption in the teaching process. It does not matter how much time is used for teaching but rather, how effectively that time is used.

Classrooms must be arranged and organized to support student learning. Classroom management involves the establishment and maintenance of the classroom environment. Central to effective management is the ability to provide a positive physical environment for students' learning and well-being (Moore, 2001).

Classroom management consists of the following features (Arı and Deniz, 2008):

1. Physical arrangement of the educational environment

2. Activities prepared for the training program

3. Effort spent for effective use of time

4. Communication arrangements between individuals and activities related to behavioral methods.

Classroom management is the process of providing a positive classroom climate by guiding the students' behavior and organizing the learning-teaching process in the classroom as student-centered. There are many elements that play a role in creating a positive learning environment in the class. Of course, one of the most important of these is that the teacher has competencies in the field of knowledge and teaching profession. It is necessary for the teacher, who is the formatter of the teaching-learning process, to have a good knowledge base and to practice the principles of classroom management. According to Lemlech (1988) "Classroom management is the management of the class as if were orchestra". Good management of the class is also a very important step in reaching the determined goals. At this stage, it is of great importance that the teacher develops the teaching-learning process as much as the formatting aspect and the managerial aspect.

Teachers have more important responsibilities in teaching. In order for the teacher to be more effective, the teacher must have five basic field skills: using time well, managing student behaviors/classroom management, giving presentations, evaluating learning, and feedback to students. The teacher is an organizer, a guide, an audience and an evaluator at the same time (Kucukahmet, 2004). Classroom management is defined as the creating a learning environment that promotes teaching activities and enhances student achievement by providing permanent learning (McLeod et al., 2003). Classroom management represents a significant aspect of the teacher's pedagogical knowledge (Emmer and Stough, 2001). The main role of the teacher is to guide and lead the students in the teaching-learning process. To adequately execute this role, the teacher must deal with the social, intellectual, and physical structure of the classroom. Classroom life consists of many things: implementation of the teaching program, provision of the necessary tools for the learning and teaching process, creating a classroom environment that promotes student success, monitoring student success, and preventing any disciplinary problems (McLeod et al., 2003). Teaching and learning cannot take place in a classroom environment with bad governance (Marzano, 2003). Therefore, effective planning of the learning and teaching process is closely related to classroom management. Brophy (1999) defines classroom management as supporting teaching and creating an environment that enhances student achievement. Trust, respect and student interest is essential for the establishment of a positive classroom environment.

In general, three elements for good classroom management may include:

a) Effective use of time and space.

b) Implementation of strategies for encouraging students to make good decisions, rather than trying to control their behavior

c) Use of effective teaching strategies (McLeod et al., 2003).

Therefore, in the context of good classroom management, the teaching strategies to be used for students' academic needs, can increase student participation and thus disciplinary problems can become more visible. The classroom atmosphere influences the quality of the student-student relationship as well as the student-teacher relationship (Grubaugh and Huston, 1990). One of the most important features of an effective teacher is to create a positive class climate. This is done by establishing a healthy and balanced relationship with the students and enabling them to reveal their behaviors in the classroom environment. This may prevent unwanted student behavior, and the need for disciplinary action. Therefore, the establishment of a rich learning environment depends on the physical arrangement of the classroom, and good planning. A rich learning environment is also very 
important for the effective use of time allocated for education and for the achievement of classroom communication. In summary, good classroom management can create a good learning climate and enable student achievements.

\subsection{Purpose of the Study}

The aim of this study is to find:

- How classroom communication should be in terms of effective classroom management in a science class?

- How student motivation should be ensured in terms of effective classroom management in science education?

- How the physical environment of the classroom should be organized for a science class?

- How to manage unwanted student behaviors in a science class?

\section{Methodology}

\subsection{Research Model}

In this research, the aim is to reveal the opinions about classroom management in the learning-teaching process of science teachers. To that effect, a qualitative research method and phenomenological design are used. The qualitative research method has been preferred in terms of subjective viewpoints, allowing depth and richness of the data to be represented (Yıldırım and Şimsek, 2013).

The interview process is one of the main data collection methods in qualitative research (Glesne, 2011). The findings of qualitative research are quite descriptive. The researcher's reflection on learning about the phenomenon is enriched by the participants and explanations of the activities. In order to support the findings of the present research, citations from the documents, field notes and sections from participant interviews are taken. These quotations contribute to the explanatory nature of study (Merriam, 2009).

\subsection{Data Collection}

The semi-structured interview form developed by the researchers is used as a data collection tool in the research. In the semi-structured interview method, the questions are prepared in advance, but questions are allowed to be rearranged and discussed with partial resistance to the persons surveyed during the interview (Ekiz, 2003). The present study seeks to answer the following question:

What is the relevance of classroom management for science teachers? A trial interview with two science teachers is conducted to determine whether or not the questions are understandable. Later, the program development department received expert opinions from two lecturers. The necessary corrections are made on the interview form examined by the lecturers. The questions are restructured and the number of questions are reduced according to lecturers' suggestions. Four questions regarding classroom management are included in the semistructured interview form, which is finalized with expert opinions.

In Mugla province of Turkey, 14 science teachers who are working in the academic year of 2015-2016 are interviewed. On May 2016, teachers are interviewed at their schools. Each interview lasted about 20 minutes. The information obtained from the teachers is recorded with a voice recorder during the interviews with permission and on the condition that all statements remain confidential.

The data is analyzed using descriptive analysis. The main purpose of descriptive analysis is to present the findings to the reader in an organized and interpreted way. The data obtained for this purpose is first described systematically and explicitly. The data obtained during the descriptive analysis is summarized and interpreted according to the previously determined theme. Later, the descriptions are explained, interpreted and concluded (Yıldırım and Şimsek, 2013). The voice recordings obtained in the research are turned into texts and then the data obtained from these interviews are analyzed and coded by reading the texts line by line in the direction of the research sub-problems. The qualitative data of the study is coded directly from the data, sometimes as a word, sometimes as a sentence. The analysis of concepts and their relation to each other are revealed and these relations, which exist among themselves, are explained with a higher-level theme. Coded data is grouped according to similarities and differences. The codes related to each other are combined and classified under the themes and interpreted.

After the interviews are coded by the investigator, the interviews are evaluated separately by another investigator and the necessary arrangements are made by discussing the issues of "opinion agreement" and "opinion disagreement." The teacher interview records are then coded by another educator and the compliance coefficient is calculated. For this purpose, the reliability formula of Miles and Huberman (1994) is used:

Agreement percentage Reliability $=\mathrm{P}=\mathrm{Na}$ (Agreement) $/(\mathrm{Na}$ (Agreement $)+\mathrm{Nd}($ Disagreement $)) \mathrm{X} 100$ (Miles and Huberman, 1994).

As a result of this calculation, the agreement coefficient is found as 86.4. According to Ylldırım and Şimsek (2013) it is assumed that the percentage of confidence is reached when the percentage of compliance in the reliability calculation is $70 \%$. The percentage of incompatibilities between coders for this study is therefore acceptable. While qualitative analysis is conducted, direct quotations are made from participating teachers to support comments. The personal information of teachers participating in the interview is kept confidential and the teachers are coded T1, T2,..T14. For example, T1 is the first teacher who participates in the interview, T5 is the fifth teacher, T14 is the fourteenth teacher.

\subsection{Working Group}

The study group consists of fourteen science teachers who worked in the province of Mugla in the academic year of 2015-2016. In the study group, 14 science teachers are selected and a diversity sampling method is used for purposeful sampling methods. The purposeful sampling method is useful in explaining facts and events in many cases (Yıldırım and Şimsek, 2013). 
In the sample, some members of the wider population will definitely be excluded and others definitely included. In purposeful sampling, researchers handpick the cases to be included in the sample on the basis of their judgment of their typicality. In this way, they build up a sample that is satisfactory to their specific needs (Cohen et al., 2000).

Table-1. Demographic Characteristics of Working Group

\begin{tabular}{l|c|c}
\hline \multicolumn{2}{c}{ Trequency } & \% \\
\hline \hline Sex Female & 10 & 71.4 \\
\hline Male & 4 & 28.6 \\
\hline $\begin{array}{l}\text { Age } \\
21-25\end{array}$ & 1 & 7.1 \\
\hline $26-30$ & 1 & 7.1 \\
\hline $31-35$ & 1 & 7.1 \\
\hline $36-40$ & 5 & 35.8 \\
\hline $41-45$ & 5 & 35.8 \\
\hline $46+$ & 1 & 7.1 \\
\hline Experience & 1 & 7.1 \\
\hline $1-5$ & 2 & 14.3 \\
\hline $6-10$ & 4 & 28.5 \\
\hline $11-15$ & 2 & 14.3 \\
\hline $16-20$ & 5 & 35.8 \\
\hline $21-25$ & - & - \\
\hline $26+$ & & \\
\hline Graduated University & 12 & 85.7 \\
\hline Faculty of Education & 2 & 14.3 \\
\hline Faculty of Science & & \\
\hline
\end{tabular}

\section{Results}

In order to be able to evaluate the effective classroom management in science teachers' classrooms, the followings are taken as inputs: opinions on classroom communication, student participation, democratic classroom environment, sincere classroom environment, and affection.

\subsection{Science Teachers' Opinions on Classroom Communication in Terms of Effective Classroom Management Includes the Followings:}

\subsubsection{Student Participation}

According to the first theme, the course attendance of learners is at the center of communication in classroom management. Teachers regard students' active participation in the course as a requirement for the communication process. They also allow the teacher to give every student a say in the classroom; only the fact that some students do not communicate with each other increases self-confidence in communication. For example, T3 stated that "That is how students can become more active. I support my students' right to speak in my classroom. If there is a question, I absolutely try to answer it. Or sometimes I get them to discuss amongst themselves. I think they make my lessons more effective. I believe the teacher should give everyone the right to speak. It should not only aimed toward talented pupils but children who are struggling should also be included for their self-confidence."

\subsubsection{Friendly Classroom Environment}

According to this theme, teachers emphasized that for the appropriate communication environment in classroom management, the student should feel comfortable in class and a cozy class environment should be created. In addition, if a teacher is "smiley" and if his or her students are addressed by name, this can create a sincere atmosphere in class management. For example, T5 stated that: "I think that it is always better for students to be able to feel very comfortable and to communicate well with each other. Sometimes it is important to be like a sister or a friend, and for the teacher to sometimes be like a friend. When a very warm and friendly class is created, children will not experience distress."

Similarly, it is stated that communication within the classroom will increase when a classroom environment can be created where students will not be afraid of teaching.

\subsubsection{Democratic Environment}

With regard to the third theme of classroom management, the establishment of a democratic environment in the class has been in the foreground of providing a space for healthy communication. In this context, in the verbal expressions of science teachers, a democratic environment is emphasized, such as giving equal rights to everyone, distributing tasks, and listening to a class while a student is speaking. For example, the science teacher T6 had the following expressions on this subject:

"First of all, the environment in the classroom must be democratic. Every teacher should acknowledge the right to speak. This should not only be given to students of certain levels, but also to children who are inadequate, in order to increase their self-confidence. On the other hand, for a democratic classroom environment in which the communication of classroom management is crucial, a free expression of opinion should be facilitated. Teacher T4 stated that "Children should be able to explain their ideas easily".

\subsubsection{Rapport with Students}

In the interviews, it is emphasized that for classroom communication, the fondness students have for their teachers and similarly the fondness teachers have for their students, increased communication within the classroom. For example, science teacher T8 expressed the following: 
"If you build rapport with students, you can do everything with it. Rapport is everything. The way to build rapport is to look children in the eye and to address them by name. Children need to hear their names as much as possible."

Emphasis is placed on the teacher's eye contact with the students in the classroom and calling on them using their first names. In this regard, science teacher T9 stated that "I observe my students; they really care for each other. They open up to each other; the student opens up when he feels he is genuinely acknowledged."

As a result, rapport can be considered very important in communication and class management. It is said that hugging him or her when a student arrives in classroom makes them feel important, regardless of their academic success and it may cause the student to pay more attention to the course works.

\subsection{Science Teachers' Opinions about Student Motivation in Terms of Effective Classroom Management Includes the Followings}

3.2.1. Use of Material

Regarding the first theme, science teachers stated that students are affected positively when using classroom management in terms of motivation to draw their attention at the beginning of the lesson. They also emphasized that during lessons, use of materials are influential in student motivation with different materials used according to the learning targets. For example, science teacher T7 expressed the following on this subject:

"For example, when I am bringing astronomy materials into the class, I get their attention and curiosity. I bring a solar system model”.

In terms of classroom management, teachers have not considered motivation, they have mostly considered curiosity as a foreground. The direct relation of science lessons with life is considered important in the formation of this curiosity. For this reason, the majority of the teachers stated that they ask questions in order to stimulate curiosity in the students, and that these questions enable the students to be motivated by the lessons.

\subsubsection{Relating the Course with Everyday Life}

In relation to the third theme, science teachers have argued that instincts are spontaneous. They try not to show students that the science lesson is already something that exists in the environment. In another way, students expressed their real life experiences by sharing their experiences and thus, motivating each other. In this regard, science teacher T12 has expressed that "The science lesson is made up of things that already exist in the environment. It's not hard to do because there are things the students see in their families, in their bodies and all around them. They do not have to imagine, because they see it all around. When I examine a plant, I say, 'Let's go out together. Let's look at the plants. "

The teacher feels the importance of the course. In relation to this theme, the teacher must find that the lesson is important and must show the students this with positive behaviors. This is very effective in the motivation of students. Science teacher T13 stated:

"The student is more important than the lesson itself. It is also easier to provide discipline in the classroom."

Do not overstress taking the exams. It is very important to point out that the students will take exams in the course of their class-oriented motivation in the classroom. It is important for the students to be motivated by proficiency exams, which have a great effect especially on the introduction to the course. Teacher T5 has this to say:

"Sometimes, some experience fear of examination. You know the national proficiency exam, I've been teaching the eighth graders this year. There is definitely one question in the exam that we will work on today. The output of the last five years will always come out again when we look at the statistic. If you listen quietly, join the lesson, and ask questions about subjects you do not understand, a question is guaranteed in the national proficiency exam because students in the eighth grade are interested in the national proficiency exam."

\subsection{Science Teachers' Views on Classroom Physical Environment in Terms of Effective Classroom Management Includes the Following}

Science teachers' opinions about the classrooms physical environment in terms of effective classroom management cover laboratory environment, U board seating, interactive whiteboards, cluster seating versus a laboratory environment in the classrooms. If we start with the first theme, the classroom does not constitute a suitable environment for science education. The process of teaching in the laboratory is effective for the students' learning. Students need to be able to do experiments themselves; laboratory rooms are needed to use materials effectively in the learning environment. The science teacher T9 said that "At the same time, I agree that science courses should be taught in complex laboratories rather than in a classic classroom. There are well-equipped laboratories to do all of them in the schools where I work. Considering we have an electrical ampere meter, voltmeter, fountain, and test tubes and more, they are well-equipped laboratories. Of course in the lab there is a separate table for everyone, so the child is learning to do it himself. The laboratory is more convenient."

\subsubsection{U Seating}

In relation to the second theme, science teachers have stated that a U-shaped seating plan should be arranged to allow face-to-face interaction between students, and between students and the teachers. Science teacher T3 stated that "The science lesson should have class environments where there are many visual items, that is, many students should be able to see the same point at the same time. In this instance, U-shaped seating may be appropriate in this regard'. In addition, it has been stated that the teachers are well suited for the purpose of ensuring the continuity of learners' active participation in this style.

The use of interactive whiteboards during class intensifies the attention of the students and contributes to learning. Using colored questions to reinforce the subject aids in examining an experiment that they cannot do with videos. According to Science Teacher T7 stated that "Physically, interactive whiteboards are very useful for us. Normally to use a projector for only 5 minutes of watching, we have to bring a computer from home and ask the principal for the cables. I did not do all of this for just 5 minutes of use. But now, even if you are teaching, the Internet is at the bottom of the list. Visual support is possible. Using technology is amazing". 
In other words, it was emphasized that visual presentations on interactive whiteboards not only increased the interest of the students but also contributed to the participation of the students. Additional information is provided by the students who attend the course, with no serious problems in terms of classroom management.

\subsubsection{Cluster Seating Arrangement}

Science teachers have stated that students practice more experimental and discussion techniques in cluster seating. In these techniques, which require co-learning in small groups, individuals are enabled to communicate better with each other. In this regard, the science teacher T12 stated that "When it is needed, the cluster format during a lesson is also great for team work. In this way a positive commitment can be made in student groups".

\subsection{Science Teachers' Views on Unwanted Behavior in Terms of Effective Classroom Management Includes the Following \\ 3.4.1. Oral Warning}

When faced with an undesirable behavior with respect to this theme, science teachers have expressed the need to warn their students. If disruptive behavior persists in the classroom, a warning is inevitable. As such, teacher T2 has claimed that "I would intervene with a verbal warning first if the unwanted behavior breaks the flow of the lesson".

\subsubsection{Try to Understand Why}

It is emphasized that knowing the reason for undesirable behavior that disrupts the lesson is important. The teacher will find it easier to remove problems if the cause of unwanted behavior is known. Science teacher T1 stated:

"We should know the student very well to start with. We need to know very well why the student does that behavior so that we can intervene. I think that we can reach a solution in a much shorter time if we already know the reason for the behavior."

Moreover, in order to understand the reason why the student has this undesirable behavior in this subject, the teacher should interview the student exhibiting the undesirable behavior at the end of the lesson and be much more effective in removing the problem.

\subsubsection{Take Responsibility}

Another tool in counteracting students' unwanted behavior that science teachers use is to give students responsibilities during classes. Responsibilities such as choosing the class president, including them in activities and providing the control of the materials given to the students are effective ways to control the unwanted behaviors. As Science Teacher T4 states:

"If you are more interested in correcting the unwanted behaviors of the students, it may be very useful for them to serve the other students. For example, you can say that I was the most mischievous class president in my previous years. Can you help me with that task?"

On the other hand, when it is noticed that the student is not participating in the lesson, the unwanted behavior can be overcome by asking the student a question in order to motivate him or her. Science teacher T6 noted:

"When you notice a student who is disconnected, asking a question to him about the lesson can draw his attention to the lesson again". Some of the science teachers from class management stated that they can correct unwanted behaviors by establishing eye contact according to the state of behavior. In other words, when students' unwanted behaviors are first noticed, such as talking to each other and turning backwards, it is very effective to correct students' behavior by establishing eye contact to make the student feel that something is wrong. In this regard, the science teacher T9 stated:

"For example, the student keeps sitting at the back rows and turning back. What can I do for discipline? I have a very stern look and I take a glance at the child immediately. I look disapproving".

\subsubsection{Punishment}

When teachers' opinions are examined, it has been observed that some teachers have punished to correct unwanted behaviors in class management process. Teachers have been using punishment as the last resort to correcting disruptive behavior. According to the science teacher T1:

"I punish the mischievous student a little further. I call on her specifically by saying 'Come on girl, answer this question for me.' She does not speak after that. She cannot do it again."

In order to minimize disruption in the classroom, science teachers make use of positive and negative reinforcements and gestures.

\section{Discussion and Conclusion}

It has been tried to determine the perceptions of science teachers in the context of communication of classroom management, motivation of students, classroom environment, and control of unwanted behaviors.

Today, there are very important philosophical changes in education as well as in every field of life. In the present educational environment, we need appropriate classrooms in which effective communication can be provided for students to develop cognitive, affective and psycho-motor skills in harmony with each other. There are many approaches in the regulation of learning experiences that come to the foreground in terms of classroom management. (Randolph and Evertson, 1994). In this study, we propose a new approach to the development of classroom management.

The findings of the research reveal that in terms of effective classroom management, the teachers-student participation in classroom communication, the democratic classroom environment, the cozy classroom environment and the expected affection that is formed between the student and the teacher are important to the teachers. These findings also show that they have adopted a constructivist approach in classroom management and that they see students at the center of communication in classroom management. Communication within the class encourages individual differences in recognizing and respecting the needs and interests of students, as well as encouraging 
students to respect each other (Akın. et al., 2016). It has been emphasized that the responsibilities of the student in this class are increased, the teacher is trying to encourage the freedom of speech, everybody is talking to student in the classroom and everybody is trying to listen to him. Also, it is necessary to address the students by their names, and to provide a sincere communication environment in which the students are trusted by their teachers and friends. While a student is speaking in classroom communication, it is stated that others listen to him and a democratic environment in which students can find answers to their questions is formed. Similarly, teachers building of rapport with students, which will be formed by students in classroom communication, can provide positive contributions to classroom management. Based on these views, the teacher-centered communication in the classroom management of the teachers is abandoned; the importance of student-centered communication can be argued to be influenced by the reform experiments that the Turkish education system had undergone constructivist understanding. Similarly, in some studies it has been determined that teachers have adopted classroom management approaches centered on more students than teacher-centered understanding (Yaşar, 2008); (Akın. et al., 2016).

According to Bayraktar (2015) while the level of lesson motivation facilitates the application of learningteaching activities to a class of high-level students, the number and size of undesirable behaviors in the classroom is reduced, thus facilitating classroom management. Strategies in effective classroom management have been developed that can be used to understand students' interests, to explain their usability, to help students develop their expectations for success, to make the class interesting, to stimulate students, to use prizes, and to create a supportive environment (Erdem, 2012). The research of teachers' opinions concerning student motivation revealed great emphasis placed on: the use of material during the lesson, asking students questions about the subject, the relation with the daily life, the importance of the lesson to the students, and the saying that the subject will be examined. In addition to this, the teachers emphasized that by using the brain storm technique, paintings and videos, teaching was not difficult by emphasizing his own external appearance in his lessons and effective classroom management could be achieved by including students in experiments. Classroom management is undeniably essential for the motivation of the students in the learning environment. This is intrinsic motivation if individuals are trying to gain satisfaction while learning. If the students are guided by an external stimulus using reinforcement, they are externally motivated (Kucukahmet, 2003). When research findings on classroom management is examined, it can be seen that the use of lesson material, asking questions about the subject, associating with the daily life, and behaving in a manner that gives importance of the lesson to the students can support more curiosity, interest, increased learning need, proficiency and development of feelings. These results support the idea that teachers in the research sample in classroom management have adopted a student-centered classroom management approach.

In terms of effective classroom management, teachers' opinions about the physical environment of classroom supported the laboratory environment, U-shape seating plan, use of interactive whiteboards and cluster seating arrangements. Teachers have often stated that having a lesson in a laboratory has a very important effect on clear learning. It has been emphasized that seeing an actual skeleton is very effective in understanding about bodies. On the other hand, some teachers' views such as lesson execution, quiet classroom environment were also obtained. Items in the classroom can also be attributed to the characteristics of the physical environment such as order, image, heating, illumination, as well as teacher and student characteristics and the number of students in the class. (Atici, 2014).

Findings in the form of verbal warning, understanding the cause of the problem, giving responsibility, establishing eye contact, punishment, interviewing parents, training the guidance counselor, and directing the students has been determined from the teachers' opinions about control of unwanted behaviors related to classroom management. From these views, it is understood that science teachers prefer to prevent unwanted behaviors by stimulating the students who express the behavior in the class. Maya and Caliskan (2004) have identified three of the most frequently cited responses to discipline research, reprimand and vocal stimulation of teachers' responses to unwanted student behaviors in vocational high school. The tone and style of the verbal warning mentioned in these opinions is very important. Students perceiving these as a punishment may lead to adverse effects on the control of unwanted behavior. It is known that penalty does not have the desired effect to create a behavior change (Kaya, 2007). The views of the science teachers that the students exhibited the unwanted behaviors can be regarded as an indication that the reactive model in the classroom management is preferred primarily in the control of the behavior. In addition, it can be said that trying to understand the cause of the problem for unwanted behaviors is a sign that teachers are concerned with classroom management. We can list the reasons for the behavior that the student demonstrates as effective methods to reduce unwanted student behaviors (Aydin, 1998). When students show unwanted behavior or when students have a conflict, Glasser suggests an approach that is systematic, clearcut, open communication-based, giving the responsibility to change student behaviors and change their behavior (Atıcı, 2003). Behaviors such as teachers trying to understand the cause of the problem and giving responsibility can be related to the problem solving approach in Glasser's classroom management. It is a grave mistake that unwanted student behavior is dealt with by having the child taken out and sent to the guidance counselor, sometimes even without talking with the child. Directing the student to the guidance service in this way is against the principles of volunteering, one of the most important guiding principles (Siyez, 2009). In addition, teachers' views such as changing the tone of voice, giving advice, expressing this behavior wrong in class, and calling the student to the board were also obtained from the findings.

This study reflects the opinions of teachers for those who organize education policies in the Turkish education system, communication in effective classroom management, classroom environment, motivation of learners and control of unwanted behavior. This study, which includes the views of science teachers about classroom management, can be supported by other data sources in different disciplines and in different classrooms. It is believed that teachers reflect more on their communication, motivation, classroom environment regulation and control of unwanted behaviors. 


\section{References}

Akın., S., A. Yıldırım and A.L. Goodwin, 2016. Classroom management through the eyes of elementary teachers in Turkey: A phenomenological study. Educatıonal Sciences: Theory \& Practice, 16(3): 771-797. View at Google Scholar | View at Publisher

Arı, R. and M.E. Deniz, 2008. Classroom management. Ankara: Maya Akademi.

Atıc1, M., 2003. The application of glasser's problem solving approach dealing with misbehaviour. Educational Science, 28(128): 27-34. View at Google Scholar

Atıc1, R., 2014. Student attitudes in class factor saffecting. International Journal of Social Science, 28(2): 413-427.

Aydın, A., 1998. Classroom management. Ankara: Anı.

Bayraktar, V.H., 2015. Student motivation in classroom management and factors that affect motivation. Turkish Studies, 10(3): 1069-1090.

Brophy, J., 1999. Perspectives of classroom management. In H. J. Freiberg (Ed.), Beyond Behaviorism: Changing The Classroom Management Paradigm. Boston: Allyn \& Bacon. pp: 43-56.

Cohen, L., L. Manion and K. Morrison, 2000. Research methods in education. 5th Edn., US: Routledge Falmer.

Ekiz, D., 2003. Introduction to research methods and techniques in education. Ankara: Anı.

Emmer, E.T. and L.M. Stough, 2001. Classroom management: A critical part of educational psychology, with implications for teacher education. Educational Psychologist, 36(2): 103-112. View at Google Scholar |View at Publisher

Erdem, A.R., 2012. Motivation and effective classroom management in classroom. Ed. Huseyin Kiran. Ankara: Ani.

Evertson, C.M., E.T. Emmer, B.S. Celements and M.E. Worsham, 1997. Classroom management for elementary teachers. 4th Edn., Boston: Allyn and Bacon.

Glesne, C., 2011 . Becoming qualitative researchers: An introduction. 4th Edn., Boston, MA: Pearson.

Good, T.L. and J.E. Brophy, 2008. Looking in classrooms. 10th Edn., US: Pearson.

Grubaugh, S. and R. Huston, 1990. Establishing a classroom environment that promotes interaction and improved student behavior. Clearing House, 63(8): 375-378. View at Google Scholar |View at Publisher

Jones, F., 2000. Tools for teaching: Discipline, instruction, moti califorvation. Nia: Frederic Jones and Associates.

Kaya, A., 2007. Operant conditioning. A. Kaya (Ed.), Egitim Psikolojisi. Ankara: Pegem A.

Kucukahmet, L., 2003. New approaches in classroom management. Ankara: Nobel Yayınevi.

Kucukahmet, L., 2004. Classroom management. 6th Edn., Ankara: Nobel.

Lemlech, J.K., 1988. Classroom management. 2nd Edn., New York: Longman Inc.

Levine, L., 2009. Teaching comprehension with questioning strategies that motivate middle school readers. New York: Scholastic Teaching Resources.

Mackanzie, R.J. and L. Stanzione, 2010. Setting limits in the classroom. A complete guide to effective classroom management with a schoolwide discipline plan. 3th Edn., New York.US: Crown Publishing Group.

Marzano, R.J., 2003. Clasroom management that works: Research-based strategies for every teacher. Alexandria, VA, USA: Association for Supervision \& Curriculum Development.

Maya, I. and H. Caliskan, 2004. Characteristics of the primary schools and levels of organizational conflict (example of İzmir province). Journal of Educational Researches, 14(2): 200-2 10.

McLeod, J., J. Fisher and G. Hoover, 2003. The key elements of classroom management: Managing tiem and space, student behavior, and instructional strategies. USA: ASCD.

Merriam, S.B., 2009. Qualitative research. A guide to design and implementation. US: John Wiley and Son Ltd.

Miles, M., B. and A.M. Huberman, 1994. Qualitative data analysis: An expanded sourcebook. 2nd Edn., Thousand Oaks, CA: Sage.

Moore, K.D., 2001. Classroom teaching skills. 5th Edn., New York: McGraw Hill.

Randolph, C.H. and C.M. Evertson, 1994. İmages of management for learner - centered classroom. Action in Teacher Education, 16(1): 5564. View at Google Scholar

Roelofs, E., V. Simon and R. Jan, 1994. Improving instruction and classroom management behavior in mixed-age classrooms: Results of two improvement studies. Educational Studies, 20(1): 105-127. View at Google Scholar | View at Publisher

Siyez, D.M., 2009. High school teachers' perceptions of and reactions towards the unwanted student behaviors. Pamukkale University Faculty of Education Journal, 25(1): 67-80. View at Google Scholar

Yaşar, S., 2008. Classroom management approaches of primary school teachers. Master's Thesis, Middle East Technical University, Ankara.

Yıldırım, A. and H. Şimsek, 2013. Qualitative research methods in social sciences. 9th Edn., Ankara: Seckin. 